\title{
THE ANEMIA OF INFECTION. XIV. RESPONSE TO MASSIVE DOSES OF INTRAVENOUSLY ADMINISTERED SACCHARATED OXIDE OF IRON ${ }^{1}$
}

\author{
W. J. KUHNS,2 C. J. GUBLER, G. E. CARTWRIGHT, AND M. M. WINTROBE \\ (From the Department of Medicine, College of Medicine, University of Utah, \\ Salt Lake City, Utah)
}

(Submitted for publication July 10, 1950; accepted, August 16, 1950)

The anemia of infection is associated with a number of alterations in iron metabolism. Previous studies $(1-4)$ have shown that, with the development of inflammation, hypoferremia occurs and a decrease takes place in the concentration of the metal binding protein in the plasma. When iron is given by mouth, there is little change in the level of plasma iron and, following the intravenous injection of iron, only a transient rise in the plasma iron develops. These findings have suggested that diversion of iron from the plasma takes place in inflammation and infection. Studies in experimental animals have shown that iron is diverted primarily to the liver and spleen. Whether this iron is simply stored, since less can be used in the face of diminished hemoglobin production, or performs a special function in connection with the presence of inflammation, is unknown.

These findings contrast with those associated with iron deficiency anemia where, although hypoferremia is present, there is a considerable increase in the concentration of metal binding protein in the plasma. In iron deficiency anemia the oral or intravenous administration of iron results in increased hemoglobin production. If the amounts given are adequate, this is followed ultimately by a return of the plasma iron and the quantity of metal binding protein to normal.

That reduced iron intake is not the limiting factor in the anemia associated with infection was suggested by the fact that the intravenous administration of relatively large amounts of iron failed to relieve it (1-8). A defect in these studies, as carried out in human subjects, however, was that the administration of preparations such as iron ascorbate (10 to $300 \mathrm{mg}$.) was attended by local and

\footnotetext{
1 Aided by grants from the United States Public Health Service and the Upjohn Company, Kalamazoo, Michigan.

2 Postdoctorate Fellow of the United States Public Health Service.
}

systemic reactions and consequently the amounts of iron given were not as great as might have been desired.

The recent development (9) of a comparatively non-toxic intravenous iron preparation, saccharated oxide of iron (Ferrivenin), which is effective clinically in iron deficiency states (10) has provided a means whereby massive single doses, even as great as $1 \mathrm{gm}$. (as elemental iron), may be given, generally without concomitant untoward side effects. It was thought, therefore, that by this means a more adequate investigation of the possible limiting effect of iron on hemoglobin production in the presence of inflammation might be made.

In the present study, 14 patients with hypoferremia associated with infection, in 13 instances accompanied by anemia, were given saccharated oxide of iron intravenously in amounts which varied from 0.8 to $2.2 \mathrm{gm}$. of elemental iron. For purposes of comparison, three patients with an iron deficiency anemia were treated similarly. In addition, the urinary excretion of iron was measured in three patients and tissue iron analyses were made in two cases.

\section{METHODS}

Saccharated oxide of iron (Ferrivenin) was provided as an aqueous solution in sterile ampules, each of which contains $0.1 \mathrm{gm}$. of elemental iron. The contents of one ampule were mixed with $15 \mathrm{ml}$. of normal saline solution and this was injected slowly over a period of two minutes into an arm vein. When as much as $1.0 \mathrm{gm}$. was to be given, the contents of ten ampules were diluted in $500 \mathrm{ml}$. of normal saline solution and this was then administered as an intravenous drip over a two hour period.

The dosage schedule and total dose varied in individual patients. The general plan of treatment was to administer $1.0 \mathrm{gm}$. of iron initially and to follow this with $0.1 \mathrm{gm}$. daily during the ensuing week. The average quantity of iron given to 14 patients was $1.6 \mathrm{gm}$., but ranged from $0.8 \mathrm{gm}$. to $2.2 \mathrm{gm}$. For the purpose of studying the disappearance rate of iron from the plasma with increasing 
TABLE I

Blood values in patients with rheumatoid arthritis prior to intravenous iron administration

\begin{tabular}{l|c|c|c|c}
\hline \hline Patient & VPRC* & $\begin{array}{c}\text { Serum } \\
\text { iron }\end{array}$ & $\begin{array}{c}\text { Total iron } \\
\text { binding } \\
\text { capacity } \\
\text { of serum }\end{array}$ & $\begin{array}{c}\text { Serum } \\
\text { copper }\end{array}$ \\
\hline & $\begin{array}{c}\text { ml. per } \\
100 \mathrm{ml} .\end{array}$ & $\begin{array}{c}\mu g . \text { per } \\
100 \mathrm{ml} .\end{array}$ & $\begin{array}{c}\mu g . \text { per } \\
100 \mathrm{ml} .\end{array}$ & $\begin{array}{c}\mu g . \text { per } \\
100 \mathrm{ml} .\end{array}$ \\
J. F. & 37 & 36 & 286 & 204 \\
L.P. & 38 & 50 & 300 & 160 \\
H.J. & 41 & 40 & 240 & 154 \\
D. A. & 40 & 35 & 285 & 154 \\
J.O. & 38 & 30 & 180 & \\
L.S. & 31 & 38 & 188 & \\
Normal & 47.1 & 104.7 & 359.0 & 118.6 \\
$* *$ & \pm 2.4 & \pm 32.8 & \pm 30.8 & \pm 12.5 \\
\hline
\end{tabular}

* VPRC refers to volume of packed red cells.

** Means \pm standard deviation. doses, $0.01,0.1$ and $1.0 \mathrm{gm}$. of iron were administered on successive days, in the manner already described.

Hemoglobin, volume of packed red cells, corpuscular indices, reticulocyte and serum iron determinations were made at frequent intervals during and after the period of iron administration. Baseline observations generally were made for a period of five days. The period of iron administration ranged from seven to 12 days. Follow-up periods ranged from three weeks to four months.

Selection of each case was made by measuring serum iron, serum copper and total serum iron binding capacity. Serum iron was estimated according to the method of Barkan and Walker (11). Serum copper was determined by the method of Cartwright, Jones and Wintrobe (12) and total iron binding capacity by the technique of Schade and Caroline as modified by Cartwright and Wintrobe (4). For all of the measurements recorded in this report, serum was used. We have found that

TABLE II

Hematopoietic response of patients to massive doses of iron given intravenously

\begin{tabular}{|c|c|c|c|c|c|c|c|c|c|}
\hline $\begin{array}{l}\text { Patient } \\
\text { or } \\
\text { reference }\end{array}$ & Diagnosis & $\begin{array}{l}\text { Amount } \\
\text { of iron } \\
\text { given }\end{array}$ & $\underset{\text { initial }}{\text { Hgb }}$ & $\begin{array}{c}\text { Hgb } \\
30 \text { days } \\
\text { following } \\
\text { treatment }\end{array}$ & $\begin{array}{l}\text { Mean Hgb rise } \\
\text { per day for } \\
30 \text { day period } \\
\text { following } \\
\text { treatment }\end{array}$ & $\begin{array}{l}\text { Retic } \\
\text { increase }\end{array}$ & $\begin{array}{c}\text { Serum } \\
\text { iron } \\
\text { initial }\end{array}$ & $\begin{array}{l}\text { Serum } \\
\text { iron at } \\
\text { termina- } \\
\text { tion of } \\
\text { study }\end{array}$ & $\begin{array}{l}\text { Clinical condition } \\
\text { at termination } \\
\text { of study }\end{array}$ \\
\hline & & $(\mathrm{gm})$. & $\underset{\operatorname{per}(\mathrm{gm})}{\text { cent })}$ & $\underset{\text { per cent })}{(g m .}$ & (gm. per cent) & (per cent) & $\begin{array}{l}\text { (ug. } \\
\text { per cent) }\end{array}$ & $\begin{array}{l}\text { (ug. } \\
\text { per cent) }\end{array}$ & \\
\hline $\begin{array}{l}\text { Slack and } \\
\text { Wilkinson } \\
\text { (average } \\
\text { of series) }\end{array}$ & $\begin{array}{l}\text { Iron } \\
\text { deficiency } \\
\text { anemias }\end{array}$ & 0.92 & 7.3 & 12.5 & $\begin{array}{c}0.184 \\
\text { (21-35 days) }\end{array}$ & $10-18$ & & & \\
\hline $\begin{array}{l}\text { Goetsch, } \\
\text { Moore and } \\
\text { Minnich }\end{array}$ & $\begin{array}{l}\text { Iron } \\
\text { deficiency } \\
\text { anemias }\end{array}$ & $0.608-1.32$ & 8.0 & & 0.224* & & & & \\
\hline Y. G. & $\begin{array}{l}\text { Iron } \\
\text { deficiency } \\
\text { anemia }\end{array}$ & 0.875 & 8.1 & 12.6 & 0.15 & 5.8 & 25 & 43 & $\begin{array}{l}\text { Considerable clinical } \\
\text { improvement }\end{array}$ \\
\hline D. A. & $\begin{array}{l}\text { Chronic } \\
\text { rheumatoid } \\
\text { arthritis }\end{array}$ & 1.7 & 13.8 & 15.3 & 0.05 & 2.8 & 47 & 40 & No improvement \\
\hline J. 0 . & $\begin{array}{l}\text { Chronic osteo- } \\
\text { myelitis; } \\
\text { Chronic } \\
\text { rheumatoid } \\
\text { arthritis }\end{array}$ & 2.0 & 12.5 & 13.8 & 0.04 & 2.7 & 35 & 43 & No improvement \\
\hline L. $P$. & $\begin{array}{l}\text { Chronic } \\
\text { rheumatoid } \\
\text { arthritis }\end{array}$ & 1.8 & 14.2 & 13.9 & $\mathbf{0}$ & 2.5 & $\begin{array}{l}61 \\
.\end{array}$ & 86 & Slight improvement \\
\hline M. R. & $\begin{array}{l}\text { Acute pyelo- } \\
\text { nephritis }\end{array}$ & 1.8 & 13.5 & 14.3 & 0.03 & 2.1 & 32 & 41 & $\begin{array}{c}\text { Moderate improve- } \\
\text { ment }\end{array}$ \\
\hline M. D. & $\begin{array}{l}\text { Pelvic inflam- } \\
\text { matory } \\
\text { disease }\end{array}$ & 1.2 & 11.6 & 11.6 & $\mathbf{0}$ & 2.1 & 45 & 71 & $\begin{array}{l}\text { Moderate improve- } \\
\text { ment }\end{array}$ \\
\hline L. $\mathbf{S}$. & $\begin{array}{l}\text { Disseminated } \\
\text { lupus ery- } \\
\text { thematosus }\end{array}$ & 2.0 & 10.1 & 7.8 & $\mathbf{0}$ & 1.9 & 42 & 40 & Died \\
\hline H. J. & $\begin{array}{l}\text { Chronic } \\
\text { rheumatoid } \\
\text { arthritis }\end{array}$ & 1.9 & 15.1 & 13.0 & $\mathbf{0}$ & 2.6 & 43 & 36 & No improvement \\
\hline P. L. & $\begin{array}{l}\text { Chronic } \\
\text { pulmonary } \\
\text { disease }\end{array}$ & 0.8 & 13.8 & 16.1 & 0.077 & 7.0 & & & $\begin{array}{l}\text { Considerable clinical } \\
\text { improvement during } \\
\text { course of therapy }\end{array}$ \\
\hline J. F. & $\begin{array}{l}\text { Chronic } \\
\text { rheumatoid } \\
\text { arthritis }\end{array}$ & 0.85 & 12.1 & 14.2 & 0.070 & 3.2 & & & Slight improvement \\
\hline
\end{tabular}

* Number of days followed not stated. 
serum and plasma values for iron, copper and iron binding capacity are identical. Iron analyses of unperfused tissue specimens, purulent exudate and urine were made by a technique described elsewhere (13).

Fourteen patients with the anemia or hypoferremia of infection were treated. Patients with chronic rheumatoid arthritis were included in this category since the chemical pattern of serum iron and iron binding capacity in this disorder is similar to that found in infections (Table I). Adequate follow-up data were obtained in ten patients. These are presented in Table II. The remainder could not be studied further, either due to death (two patients), or operation followed by multiple transfusions and subsidence of infection (two patients).

\section{RESULTS}

Reactions following the administration of Ferrivenin were moderately frequent, particularly with the larger doses, and varied from local thrombophlebitis to a general shock-like reaction (Table III). The latter was observed in two patients

TABLE III

Reactions to intravenous iron therapy

$\begin{array}{lcc}\text { Type } & \begin{array}{c}\text { Number of } \\ \text { patients }\end{array} & \begin{array}{c}\text { Size of dose } \\ (\mathrm{gm} .) \\ 0.1-1.0\end{array} \\ \begin{array}{l}\text { None } \\ \text { Transient } \\ \text { pain in back and chest } \\ \text { dyspnea, headache }\end{array} & 9 & \\ \begin{array}{c}\text { nausea, vomiting, diarrhea } \\ \text { Moderately severe } \\ \text { nausea, vomiting, diarrhea } \\ \text { shocklike state } \\ \text { thrombophlebitis }\end{array} & 5 & 0.1-1.0 \\ \begin{array}{l}\text { Severe } \\ \text { pain in back and chest } \\ \text { shock, dyspnea } \\ \text { nausea, vomiting }\end{array} & 2 & 0.2-1.0 \\ & & \\ \end{array}$

who received $0.85 \mathrm{gm}$. of a proposed $1.0 \mathrm{gm}$. single dose. In these individuals, severe generalized chest, abdominal and back pain were associated with a transient fall in blood pressure. This was followed by marked apprehensiveness, excessive perspiration, dyspnea, nausea, vomiting and diarrhea. Oxygen was given by nasal catheter, following which moderate relief occurred. These symptoms persisted for from six to eight hours, after which time there were no apparent residual manifestations apart from sensations of fatigue.

Three other patients experienced brief episodes of dyspnea and back pain following the injections of iron. Three noticed several episodes of nausea and diarrhea in a 12 hour period following iron administration. Two patients with chronic rheumatoid arthritis complained of an increase in

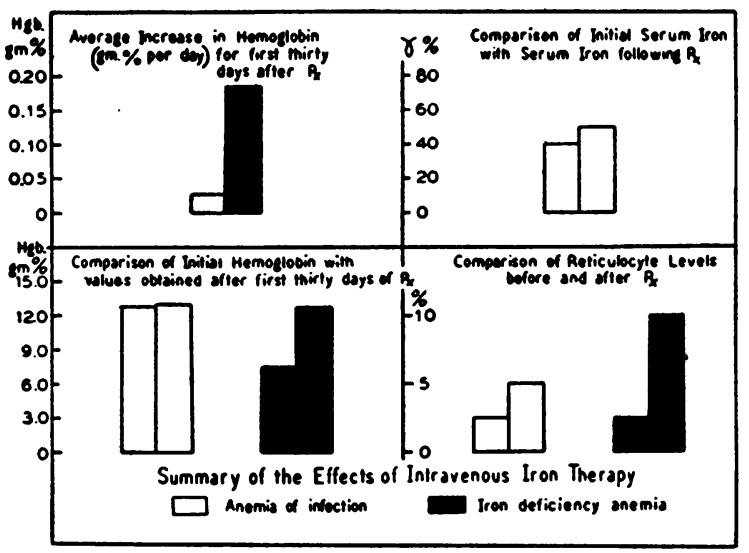

Fig. 1. Average Increase in Hemoglobin 30 Days following Intravenous Iron Therapy in Patients With Infections Compared with Marked INCREASE in Patients with Iron Deficiency Anemia and ComPARATIVE EFfects ON Hemoglobin LeVEL AND ReticuLOCYTE Response IN THe Two Groups

The lack of significant alteration in serum iron in the patients with infection is also shown.

joint pains subsequent to administration of the initial dose of iron. Nine patients experienced no difficulties at any time during the course of iron administration.

A summary of the effect of intravenous iron therapy is presented in composite form in Figure 1. Despite the administration of massive doses of iron, it was not possible to correct the hypoferremia in any instance where the associated infection persisted throughout and following the course of therapy (Figures 2-5). The administration of $1 \mathrm{gm}$. doses was accompanied by serum iron in-

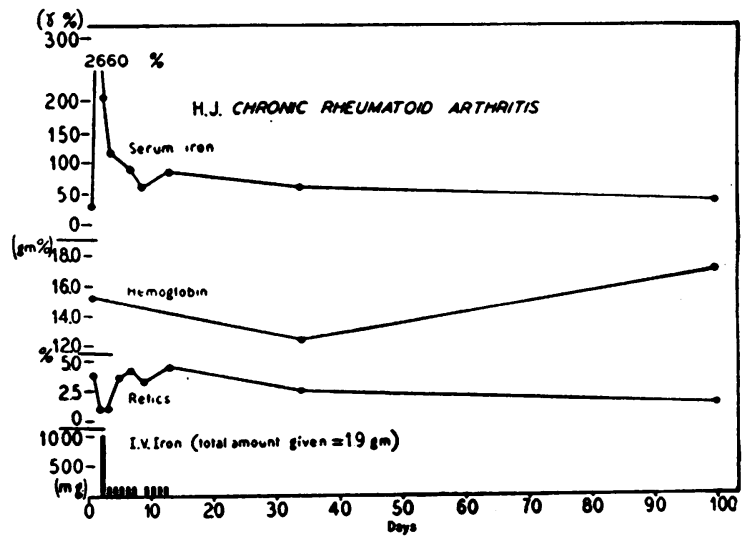

Fig. 2. Serum Iron, Hemoglobin and Reticulocyte Changes in a Patient with Chronic Rheumatoid Ar-

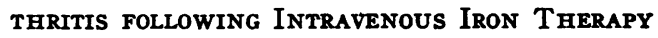




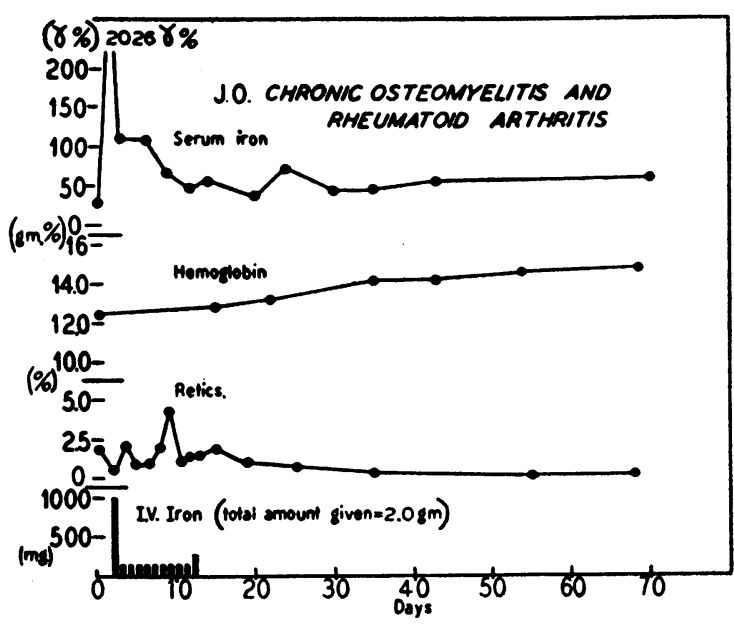

Fig. 3. Serum Iron, Hemoglobin and Reticulocyte Changes in a Patient with Chronic Rheumatold Osteomyelitis and Rheumatoid Arthritis folLOWING INTRAVENOUS IRON THERAPY

creases amounting to 1,500 to $3,700 \mu \mathrm{g}$. per cent as measured immediately following the two hour period of infusion. Where single $1 \mathrm{gm}$. quantities were given in the presence of persistent infection, the previously low serum iron levels were restored three to five days after iron administration. In comparable instances where $0.1 \mathrm{gm}$. quantities were given, the return to low serum iron levels was considerably more rapid, and took place in less than 24 hours.

The rate of disappearance of iron from the serum was studied in a normal individual and compared with the rate of disappearance of iron from the serum of a patient with chronic empyema. Both

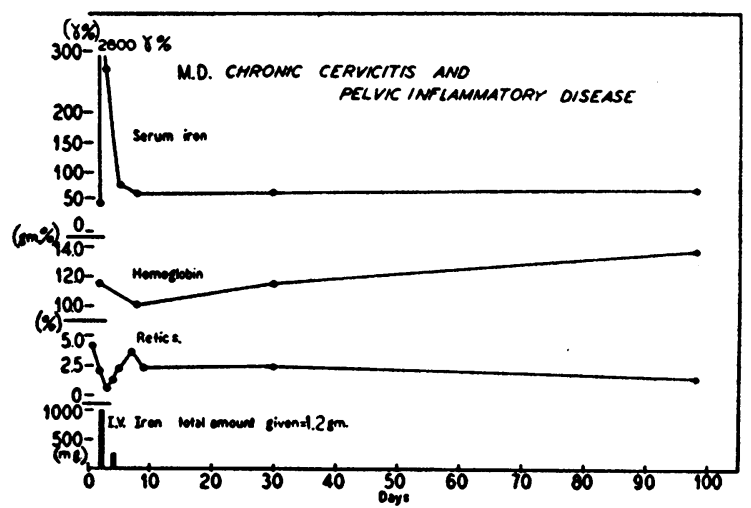

Fig. 4. Changes in Serum Iron, Hemoglobin and Remculocytes in a Patient with a Chronic InfecTION Treated with Intravenous IroN patients were given $0.010,0.10$ and $1.0 \mathrm{gm}$. of iron intravenously on successive days. There was a noteworthy tendency in the normal individual to reach higher post-injection serum iron levels than in the patient with empyema. In both cases there was an early tendency to return to pre-existing values. In the normal subject $(H . C$.) normal values from serum iron were restored and in the patient with chronic empyema (G. Y.) the previous subnormal levels were attained in a comparable period of time.

On the other hand, correction of hypoferremia in the iron deficient patients took place within a few days following the initiation of therapy, and the normal serum iron level was maintained in

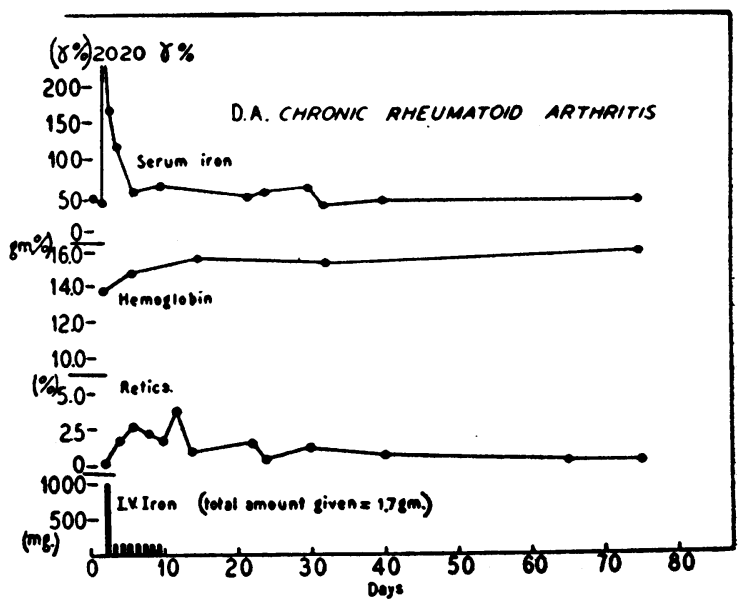

Fig. 5. The Effect of Intravenous Iron Therapy on the Serum Iron, Hemoglobin and Reticulocytes in a Patient with Chronic Rheumatord Arthritis

those instances where sufficient iron was given to make up for the calculated deficit (Figure 6). In one such case where the total calculated amount was not given (Figure 7), the patient experienced a good reticulocyte response, and the rise in hemoglobin was maintained, but the serum iron level in subsequent weeks fell to the previous low levels.

Of note is the fact that one treated patient (W. D.) who initially had chronic osteomyelitis of the foot which was associated with anemia and hypoferremia, later had the affected member amputated. Shorty after operation, the serum iron values rose to normal and were so maintained until several months later when the patient returned because of multiple bone fractures, at which time he again exhibited anemia and hypoferremia. 


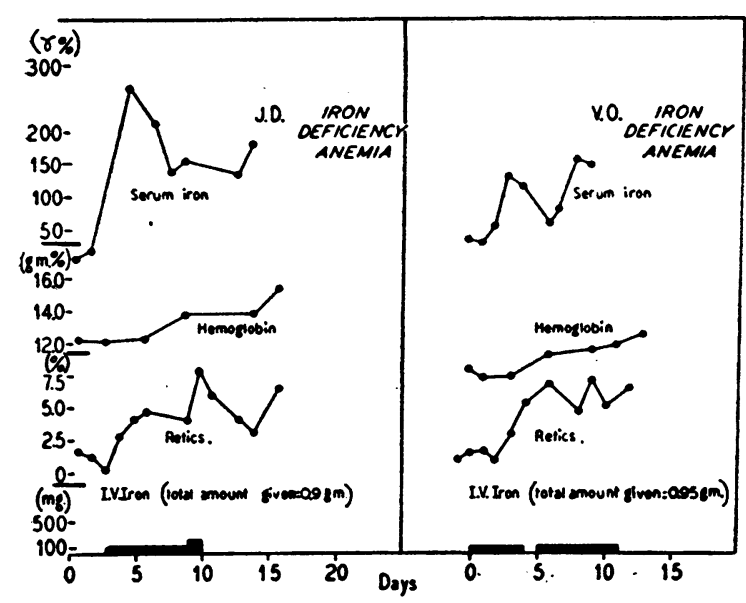

Fig. 6. Serum Iron, Hemoglobin and Reticulocyte Changes following Intravenous Iron Therapy in Two Patients with Mild Iron Deficiency Anemia

The reticulocyte response to the intravenous injection of iron was slight in degree (Figures 1-5). This was in marked contrast to the findings in iron deficient patients with comparable initial hemoglobin levels who exhibited a prompt and sustained reticulocytosis (Figures 1,6 , and 7 ) which, incidentally, was greater in degree than the expected levels following oral administration of iron (14).

In two patients with chronic infection, an increase in reticulocytes to 7.0 per cent and 11.6 per cent, respectively, was observed. In the first case (P. L.) there was at the same time actual clinical improvement, subsidence of the infection subsequent to antibiotic therapy, and a rise in serum

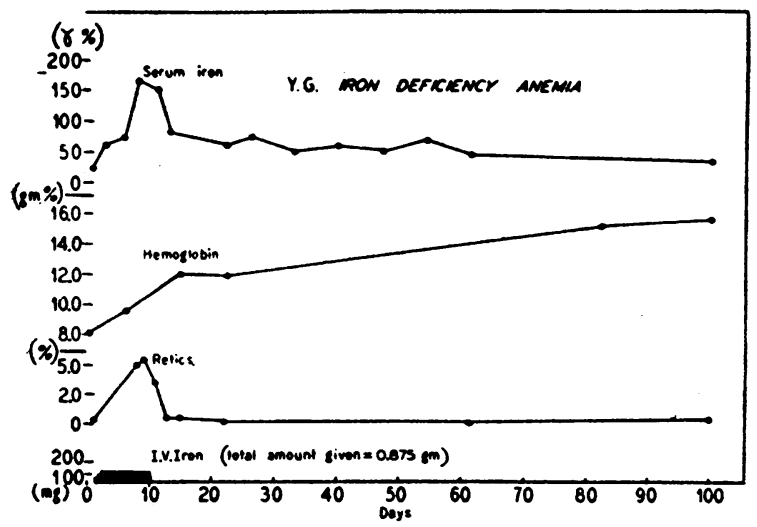

Fig. 7. Serum Iron, Hemoglobin and Reticulocyte Changes following Intravenous Iron Therapy in a Patient with Moderately Severe Iron Deficiency ANEMia iron levels during the course of iron therapy. In the second patient (G. D.) the baseline values were increased somewhat above normal, and subsequent values were all rather high; a source of bleeding was suspected in addition to the infection (empyema) although none was ever demonstrated. That he was anemic as the result of his infection was suggested by the low iron binding capacity (4).

A detailed comparison of individual hemoglobin responses following intravenous iron therapy is presented in Table II. Prolonged follow-up studies in the group with infection were frequently difficult to evaluate because of subsidence or disappearance of the infection. For this reason, the

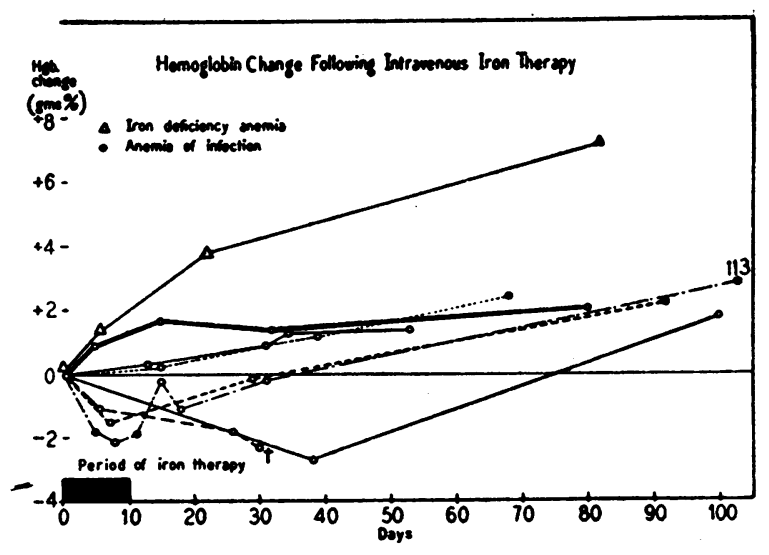

Fig. 8. Comparison of Rise in Hemoglobin following Intravenous Iron Therapy in one Patient with Iron Deficiency Anemia with the Small Changrs in Hemoglobin in Nine Patients with Anemia of INFECTION

average daily rise in hemoglobin following therapy was calculated only for the initial 30 day period, during which time the clinical status in most instances remained relatively constant. On this basis, the average mean daily hemoglobin rise in the group studied was $0.035 \mathrm{gm}$. per cent with extremes of 0 and $0.087 \mathrm{gm}$. per cent (Table II). On the other hand, in treated iron deficient patients in our own limited series and in those of other investigators $(10,15)$ daily responses ranged from 0.14 to $0.27 \mathrm{gm}$. per cent.

Comparison of the initial average hemoglobin values with those obtained 30 days after the initiation of therapy, demonstrated a negligible increase in the group with infection, whereas an 
average increase of $5 \mathrm{gm}$. per cent occurred in the patients with iron deficiency. Unfortunately the figures are not strictly comparable due to the higher initial hemoglobin values in the former series. However, a comparison between individual patients with similar initial levels in each group (Figures 3,4 , and 6 ) yields confirmatory findings.

Figure 8 illustrates the hemoglobin change over relatively long periods of time ( 30 to 113 days) subsequent to therapy in one case of iron deficiency anemia and in seven patients with infection and anemia. The iron deficient patient showed an immediate and prolonged hemoglobin rise, from $8.1 \mathrm{gm}$. per cent to $15.8 \mathrm{gm}$. per cent over an 82

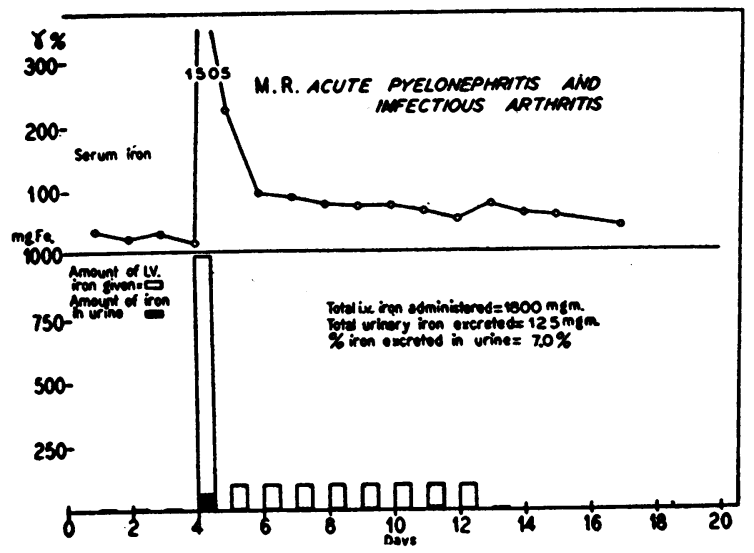

Fig. 9. The Urinary Excretion of Iron in a PaTIENT WITh Chronic INFECTION FOLlOWING THE INTRAvenous Administration of Large Doses of Iron

day follow-up period. Hemoglobin responses in the group with infection and anemia generally consisted of a very slow rise over a relatively long period of time, or an initial decrease followed by a rise. In four patients with initial hemoglobin levels which ranged from 10.1 to $15.1 \mathrm{gm}$. per cent, a decrease in hemoglobin took place following the intravenous injections of iron. This was followed by a slow rise over a protracted period, except in one patient who died one month following treatment. The progressive hemoglobin increase was variable in degree but always was distinctly less than in comparable iron deficient patients. In one patient (P. L.) in whom there was a hemoglobin increase from $13.8 \mathrm{gm}$. to $16.1 \mathrm{gm}$. in the 30 days following treatment, there was distinct evidence

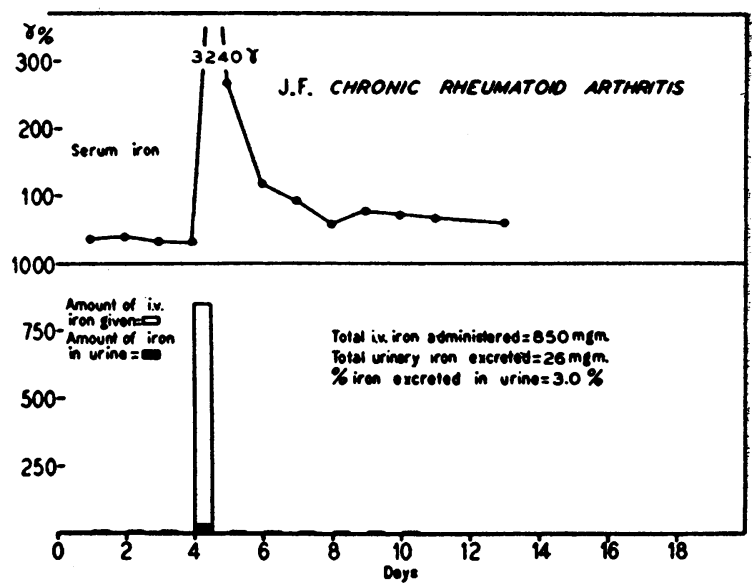

Fig. 10. The Urinary Excretion of Iron in a Patient with Chronic Infection following a Single LARGE INTRAVENOUS INJECTION OF IRON

of clinical improvement on antibiotic therapy and a rise in hemoglobin levels during the course of iron therapy. Two other patients (J. F., G. D.) showed somewhat similar, but not as great, improvement following iron therapy (see Table II).

In attempts to demonstrate possible loss of iron given intravenously to patients with the anemia of infection, the urinary excretion of iron was measured before, during and after the period of iron administration. The results in three patients are presented in Figures 9, 10 and 11 and in Table IV. These indicate that the urinary excretion of iron during the periods of study was of small magnitude in comparison with the total amounts administered.

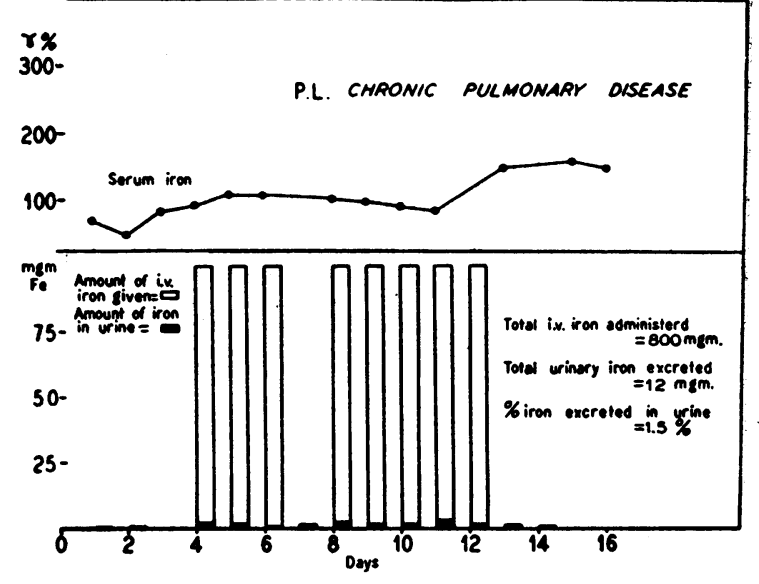

Fig. 11. The Urinary Excretion of Iron in a Patient with Chronic INFECtion following Multiple INTRAVENOUS INJECTIONS OF IRON 
TABLE IV

Urinary iron excretion in four patients treated with saccharated oxide of iron

\begin{tabular}{|c|c|c|c|c|}
\hline Patient & Disease & $\begin{array}{c}\text { Total } \\
\text { amount } \\
\text { of iron } \\
\text { administered }\end{array}$ & $\begin{array}{c}\text { Total } \\
\text { urinary } \\
\text { iron } \\
\text { excretion }\end{array}$ & $\begin{array}{c}\text { Per cent } \\
\text { of total } \\
\text { iron } \\
\text { excreted }\end{array}$ \\
\hline M. R. & Acute pyelo- & $\begin{array}{l}\text { (mg.) } \\
1800\end{array}$ & $\begin{array}{c}(m g .) \\
125\end{array}$ & 7.0 \\
\hline J. F. & Chronic rheuma- & 850 & 26 & 3.0 \\
\hline P. L. & Chronic pulmo- & 800 & 12 & 1.5 \\
\hline J. D. & $\begin{array}{l}\text { Iron deficiency } \\
\text { anemia }\end{array}$ & 900 & 7 & 0.8 \\
\hline
\end{tabular}

The total excretion ranged from 1.5 to 7.0 per cent of the iron given. The increased urinary excretion of iron lasted a relatively short period of time following the administration of Ferrivenin, and the return to normal baseline values was prompt in all cases. Urinary iron excretion was studied in one treated patient with an iron deficiency anemia. Excretion in this patient totalled 0.8 per cent during the period of iron therapy.

In one treated patient with chronic empyema and anemia, attempts were made to determine whether the administered iron was diverted to the infection site. 'The patient (G. Y.) had a chronic draining pulmonary fistula, and periodic collections of purulent material were made both before and after the intravenous administration of iron. Iron analyses were made on each sample. These showed similar values on both pre- and posttreatment specimens up to a period eight days following the administration of $0.3 \mathrm{gm}$. of iron. The amount of iron present in a $1 \mathrm{ml}$. pre-treatment specimen was found to be $18 \mu \mathrm{g}$. per cent

TABLE V

Distribution of iron in liver and spleen in two patients treated with saccharated oxide of iron and in one untreated control subject

\begin{tabular}{|c|c|c|c|c|c|c|}
\hline \multirow[t]{2}{*}{ Patient } & \multirow[t]{2}{*}{ Disease } & \multirow{2}{*}{$\begin{array}{c}\text { Amount } \\
\text { of i.v. } \\
\text { iron } \\
\text { given }\end{array}$} & \multicolumn{2}{|c|}{$\begin{array}{l}\text { Amount of iron } \\
\text { recovered in } \\
\text { tissue }\end{array}$} & \multicolumn{2}{|c|}{$\begin{array}{l}\text { Total iron } \\
\text { calculated } \\
\text { on basis of } \\
\text { organ weight }\end{array}$} \\
\hline & & & Liver. & Spleen & Liver & Spleen \\
\hline C. F.* & Acute bacterial & $\begin{array}{l}g m . \\
1.6\end{array}$ & $\begin{array}{c}\text { mg. } F e \\
\text { per } g m . \\
0.762\end{array}$ & $\begin{array}{c}\text { mg. } F e \\
\text { per } g m . \\
0.660\end{array}$ & $\begin{array}{l}\mathrm{gm} . \\
1.50\end{array}$ & $\begin{array}{l}g m . \\
0.13\end{array}$ \\
\hline L. S.* & $\begin{array}{l}\text { endocarditis } \\
\text { Disseminated } \\
\text { lupus ery- } \\
\text { thematosus }\end{array}$ & 2.2 & 0.403 & 0.763 & 0.84 & 0.38 \\
\hline C. A. & $\begin{array}{l}\text { Pneumonia and } \\
\text { arteriosclerotic } \\
\text { heart disease }\end{array}$ & $\mathbf{0}$ & 0.113 & 0.342 & 0.15 & 0.05 \\
\hline
\end{tabular}

* Iron treated patients. whereas the amount present in a similar specimen eight days after treatment was $13 \mu \mathrm{g}$. per cent. The patient showed no hematological response.

In two cases it was possible to estimate at autopsy the amount of iron diverted to the liver and spleen by comparison with autopsy specimens obtained from a patient who had not received iron previously. Iron analyses were made on unperfused samples. The results are presented in Table V. If it can be assumed that the iron was evenly distributed in the liver and in the spleen, it would appear that the liver and spleen iron was significantly increased in the iron treated subjects, in comparison with the liver and spleen iron of the untreated patient. It is of interest that in one patient (L. S.) a quantity of iron was present in the liver and spleen which was equivalent to 46 per cent of the injected iron, and in the other patient (C. F.) the concentration in these organs was equivalent to 88 per cent of the amount injected.

\section{DISCUSSION}

From these experiments it appears that neither the hypoferremia nor the anemia of infection is appreciably influenced by the intravenous administration of massive doses of iron. Although the serum iron rose considerably above normal values immediately following the intravenous infusion of iron, the level returned rather promptly to the original subnormal values in all patients in whom the infection persisted. The increases in reticulocytes and hemoglobin which followed such therapy were not great and were in no way comparable to the increases which occurred in iron deficient subjects. Although most patients who were studied for three to four months after therapy showed slightly improved hemoglobin levels, it is difficult to state whether this increase was due to the iron given or to gradual spontaneous clinical improvement.

The studies of others on the use of iron intravenously in the treatment of anemia associated with infection have yielded somewhat conflicting results. Slack and Wilkinson (10) treated two patients with spinal caries and rheumatoid arthritis and demonstrated a relative refractoriness to the intravenous administration of a large dose of iron. Hemoglobin responses occurred in both patients, but only in the course of a long follow-up pe- 
riod. On the other hand, Sinclair and Duthie (16) reported good hemoglobin responses in 16 of 23 similarly treated patients with rheumatoid arthritis. However, as there was a general inverse relationship between the curves of hemoglobin response and those of the sedimentation rate, one cannot exclude the role in hemoglobin production of clinical improvement unrelated to the administration of iron.

That the hypoferremia persisted after the administration of such large doses of iron as were given in this study is surprising and would seem to indicate that whatever the mechanism is for maintaining a low level of iron in the plasma, it is extremely powerful and cannot be easily overcome. The limited studies reported here indicate that excretion via the urine or accumulation of iron in pus does not account for the iron administered, although admittedly the failure to demonstrate an increase in the iron content of the empyema fluid of only one patient does not rule out the latter possibility. Indeed, experiments by Menkin $(17,18)$ in the rabbit have indicated that iron accumulates in the inflamed area where, it is postulated, a beneficial function may be served. Our own studies in experimental animals (19), however, would suggest that the amount of iron so diverted is by no means adequate to account for the hypoferremia.

The results of iron analyses of the unperfused liver and spleen of two iron treated patients who subsequently died as a result of their infections indicate that an amount equivalent to 46 to 88 per cent of the injected iron was found in these organs. These results confirm our earlier observation in dogs (19).

The reason for the diversion of iron from the plasma to the liver and spleen in the presence of infection is obscure. Decreased hemoglobin production does not explain the hypoferremia since in such conditions as pernicious anemia, aplastic anemia and Mediterranean anemia, hyperferremia rather than hypoferremia is usually present. Whether or not the iron is simply stored in the organs or whether it serves a special function there for which there is an increased need during infection such as in oxidation-reduction reactions, in the immune mechanism or in the production of a vasodepressor material (20) is not known. It can, however, be stated that the anemia is not the consequence of these alterations in iron metabolism since it is not alleviated by large doses of this element. The anemia must be the result of some other mechanism.

\section{SUMMARY}

1. The effects of massive amounts (1.0 to 2.2 gm.) of intravenously administered saccharated oxide of iron (Ferrivenin) were observed in $14 \mathrm{pa}$ tients with various types of infection who manifested hypoferremia and, in all but one, anemia.

2. Despite the large doses given and an elevation of serum iron immediately following treatment, in no instance where the associated illness persisted following therapy was-the hypoferremia permanently corrected.

3 . In no case was there a reticulocytosis or hemoglobin rise comparable to that obtained in patients with iron deficiency anemia. The average mean daily hemoglobin rise in 30 days following treatment was $0.035 \mathrm{gm}$. per cent with extremes of 0 and $0.087 \mathrm{gm}$. per cent, as compared with an average of $0.20 \mathrm{gm}$. per cent, with a range of 0.14 to $0.27 \mathrm{gm}$. per cent in cases of iron deficiency anemia.

4. Studies on urinary iron excretion in three treated patients with infection indicated that from 1.5 to 7.0 per cent of the iron given was excreted by this route. The excretion in one iron deficient patient represented only 0.8 per cent of the total amount given.

5. Iron analysis of purulent exudate in one treated patient with a chronic draining empyema showed no significant difference in iron content before and after the intravenous administration of $0.3 \mathrm{gm}$. of iron.

6. Iron analysis of viscera obtained from two treated patients who subsequently died showed that an amount corresponding to 46 to 88 per cent of the administered iron was recoverable in the liver and spleen.

7. The results indicate that the anemia and hypoferremia of infection are not appreciably influenced by the intravenous administration of large quantities of iron.

\section{ACKNOWLEDGMENTS}

Saccharated oxide of iron was provided by the Smith, Kline and French Laboratories, Philadelphia, Pennsylvania, through the courtesy of Dr. E. B. McLean. 
We are indebted to Miss Helen Ashenbrucker, Miss Betty Tatting and Miss Jean Robinson for technical assistance.

\section{BIBLIOGRAPHY}

1. Cartwright, G. E., Lauritsen, M A., Jones, P.J., Merrill, I. M., and Wintrobe, M. M., The anemia of infection. I. Hypoferremia, hypercupremia and alterations in porphyrin metabolism in patients. J. Clin. Invest., 1946, 25, 65.

2. Cartwright, G. E., Lauritsen, M. A., Humphreys, S., Jones, P. J., Merrill, I. M., and Wintrobe, M. M., The anemia of infection. II. The experimental production of hypoferremia and anemia in dogs. J. Clin. Invest., 1946, 25, 81.

3. Cartwright, G. E., Lauritsen, M. A., Humphreys, S., Jones, P. J., Merrill, I. M., and Wintrobe, M. M., The anemia associated with chronic infection. Science, 1946, 103, 72.

4. Cartwright, G. E., and Wintrobe, M. M., Chemical, clinical and immunological studies on the products of human plasma fractionation. XXXIX. The anemia of infection. Studies on the iron binding capacity of serum. J. Clin. Invest., 1949, 28, 86.

5. Greenberg, G. R., Ashenbrucker, H., Lauritsen, M., and Wintrobe, M. M., The anemia of infection. IV. The lack of relationship between the diversion of iron from the plasma and the origin of the anemia. J. Clin. Invest., 1947, 26, 114.

6. Schaefer, K. H., Zur Pathogenese des Infektanämie insbisondere ihre Beziehungen zum Eisenstoffwechsel des wachsenden Organismus. Klin. Wchnschr., 1940, 19, 590.

7. Schaefer, K. H., Untersuchungen über den exogenen Eisenstoffwechsel bie fieberhaften Infekten in Kindesalter. Klin. Wchnschr., 1940, 19, 979.

8. Schaefer, K. H., Gewebeeisenstoff wechsel und Hämoglobinbildung bei Infektionen. Klin. Wchnschr., 1943, 22, 98.
9. Nissim, J. A., and Robson, J. M., Preparation and standardization of saccharated iron oxide for intravenous administration. Lancet, 1949, 1, 686.

10. Slack, H. G. B., and Wilkinson, J. F., Intravenous treatment of anemia with an iron-sucrose preparation. Lancet, 1949, 1, 11.

11. Barkan, G., and Walker, B. S., Determination of serum iron and pseudohemoglobin iron with O-phenanthroline. J. Biol. Chem., 1940, 135, 37.

12. Cartwright, G. E., Jones, P. J., and Wintrobe, M. M., A method for the determination of copper in blood serum. J. Biol. Chem., 1945, 593, 160.

13. Gubler, C. J., Cartwright, G. E., and Wintrobe, $\mathbf{M}$. M., The anemia of infection. X. The effect of infection on the absorption and storage of iron by the rat. J. Biol. Chem., 1950, 184, 563.

14. Heath, C. W., and Patek, A. J., Jr., The anemia of iron deficiency. Medicine, 1937, 16, 267.

15. Goetsch, A. T., Moore, C. V., and Minnich, V., Observations on the effect of massive doses of iron given intravenously to patients with hypochromic anemia. Blood, 1946, 1, 129.

16. Sinclair, R. J. G., and Duthie, J. J. R., Intravenous iron in hypochromic anemia associated with rheumatoid arthritis. Lancet, 1949, 2, 646.

17. Menkin, V., Studies on inflammation. III. Fixation of a metal in inflamed areas. J. Exper. Med., 1930, $51,879$.

18. Menkin, V., and Menkin, M. F., The accumulation of iron in tuberculous areas. J. Exper. Med., 1931, 53, 919.

19. Greenberg, G. R., Ashenbrucker, H., Lauritsen, M., Worth, W., Humphreys, S. R., and Wintrobe, M. M., The anemia of infection. V. Fate of injected radioactive iron in the presence of inflammation. J. Clin. Invest., 1947, 26, 121.

20. Mazur, A., and Shorr, E., Hepatorenal factors in circulatory homeostasis. IX. Identification of the hepatic vasodepressor substance, VDM, with ferritin. J. Biol. Chem., 1948, 176, 771. 